\title{
Hardwoods on pine sites: competition or antagonistic symbiosis
}

\author{
Michael D. Cain \\ Southern Forest Experiment Station, USDA Forest Service, Monticello, AR 71655, USA
}

(Accepted 31 July 1990)

ABSTRACT

Cain, M.D., 1991. Hardwoods on pine sites: competition or antagonistic symbiosis. For. Ecol. Manage., 44: $147-160$.

Early development of natural loblolly (Pinus taeda L.) and shortleaf pine (Pinus echinata Mill.) regeneration was monitored in two research studies and two research demonstrations between 1980 and 1989 in southern Arkansas. Site preparation and hardwood control incorporated the use of herbicides, mechanical treatments, or prescribed burning to facilitate the establishment of natural pine regeneration in accordance with two reproduction cutting methods - selection and shelterwood - on upland pine sites. Ail treatments resulted in satisfactory density and per cent stocking of pine regeneration within the first 3 years. Growth of that regeneration excelled in one research study and on one demonstration area, but was impaired on the other two areas, apparently by an overabundance of herbaceous vegetation. Where an understory and midstory hardwood cover preceded the pine reproduction cuts, herbaceous vegetation was nearly absent and subsequent growth of the pine regeneration was excellent.

\section{INTRODUCTION}

Perpetuation of the southern yellow pine resource has been a major focus of forest management in the southeastern USA for the last 50 years. For timber utilization, pines are a more desirable resource than hardwoods on most upland sites and are the most important agricultural crop in the South (USDA Forest Service, 1988 ). Loblolly and shortleaf pines are, by far, the most abundant species.

As the successional trend across much of the southern USA is toward a hardwood forest type, even so-called 'pure pine stands' contain substantial hardwood components that compete with the pines for limited site resources. Based on field data from research studies, increasing levels of hardwood vegetation are strongly correlated with reductions in loblolly pine yield (Burkhart et al., 1987). Nevertheless, complete eradication of hardwoods from pine sites is neither feasible (Cain and Yaussy, 1984) nor desirable because hardwoods 
provide a broad array of non-timber amenities such as improved wildlife habitat, improved aesthetic effect, recreation, and fuelwood. In addition to these amenities, data reported in this paper suggest that a hardwood component in pine stands may indirectly ensure successful natural pine regeneration when harvests and accompanying cultural treatments are in accordance with recommended reproduction cutting methods.

\section{METHODS}

Data for this investigation were obtained from two active research studies and two demonstration areas on the Crossett Experimental Forest in southern Arkansas, at $33^{\circ} 02^{\prime} \mathrm{N}$ mean latitude and $91^{\circ} 56^{\prime} \mathrm{W}$ mean longitude. Elevation of the Forest is about $53 \mathrm{~m}$ with nearly level topography. Soils are predominantly Bude and Providence silt loam (Glossaquic and Typic Fragiudalfs, respectively) with an impervious layer at $46-102 \mathrm{~cm}$ that impedes internal drainage (USDA, 1979). These soils have a site index of $27 \mathrm{~m}$ for loblolly pine at base age 50 years. Annual precipitation averages $140 \mathrm{~cm}$, with extremes being wet winters and dry autumns.

Beginning in the winter of 1980-1 981 , pine seed crops were monitored annually on the Experimental Forest by taking weekly seed counts, between 1 October and 1 March from $0.2 \mathrm{~m}^{2}$ seed collection traps. An average of 24 seed traps were used each year. Collected pine seeds were cut open to determine potential viability (Bonner, 1974).

\section{Study A (selection management)}

The purpose of this study was to evaluate the efficacy of low-intensity site preparation treatments for naturally regenerating pine-deficient openings (canopy gaps) within otherwise well-stocked to overstocked uneven-aged loblolly-shortleaf pine stands with average volumes of more than $180 \mathrm{~m}^{3}$ ha- ${ }^{1}$. In addition to overstocking by pines, there had been no vegetation management in these stands for 20 years. Plots were established in openings of 0.040.32 ha that resulted from natural disturbances during the mid-1970s. The gaps were occupied with a dense growth of herbaceous and woody vegetation and there was no pine regeneration.

There were two phases to this study. Phase I had four treatments replicated three times in each of 2 years ( 1980 and 198 1) to account for variable seed crops. Phase II had three treatments replicated four times in a single year ( 198 1). All plots within Phases I and II were located within a radius of 1.6 $\mathrm{km}$. The experimental design was a randomized complete block for each phase of the study. Blocking was based on opening size within existing stand conditions. Treatments in Phase I included ( 1) untreated checks, (2) simulated logging plus hardwood injection, (3) summer burn plus foliar herbicide plus 
hardwood injection, and (4) mow plus light disking plus hardwood injection (Cain, 1987). Treatments in Phase II included ( 1) untreated checks, (2) mow plus light disking plus hardwood injection, and (3) mow plus hardwood injection in 1980 plus soil-applied herbicide in 1981 (Cain, 1987). All treatments were completed in the summer or early autumn to accommodate peak pine seedfall.

Plots in each phase of the study were 0.04 ha with measurements taken on the interior 0.02 ha. Pine seedling development and hardwood competition were assessed 8 years after the 1980 treatments and 7 years after the 1981 treatments. Measurements were taken from four circular $5 \mathrm{~m}^{2}$ subplots within each 0.02 ha interior plot. All pines were counted and the two tallest pines (dominants) per subplot were measured for total height to $0.03 \mathrm{~m}$ and groundline diameter (gld) to $1 \mathrm{~mm}$. Dominant pines were assessed as being overtopped by competing vegetation or free-to-grow.

Hardwood rootstocks were enumerated by species on the same four subplots for stems greater than $15 \mathrm{~cm}$ tall. Height of hardwoods was measured to the nearest $0.3 \mathrm{~m}$ up to $6 \mathrm{~m}$, then to the nearest $1.5 \mathrm{~m}$ if taller than $6 \mathrm{~m}$. Each subplot was evaluated for per cent cover by pines, hardwoods, or herbaceous species based on visual estimation to the nearest $10 \%$.

\section{Study B (shelterwood)}

The purpose of this study was to assess the effects of prelogging hardwood control for establishment of natural pine regeneration. When the study began in 1983, there was an even-aged stand of mature loblolly and shortleaf pines that averaged $51 \mathrm{~cm}$ in diameter at breast height (dbh) and contained about $23 \mathrm{~m}^{2}$ ha- ${ }^{-}$basal area with an understory and midstory hardwood density of 17300 stems ha- '. Midstory hardwoods averaged $5 \mathrm{~m}$ in height. Submerchantable pines of less than $9.1 \mathrm{~cm}$ dbh, averaged only 156 stems ha- '.

Three hardwood control treatments and an untreated check were replicated four times on 0.10 ha plots in a randomized complete block design. Blocking was based on initial overstory pine basal area within plots. Hardwoods were controlled by ( 1) stem injection, (2) soil-applied herbicide, and (3) mowing or chain-saw cutting plus a broadcast foliar herbicide (Cain, 1988a). These hardwood control treatments were applied only once, in spring or early summer 1983.

After hardwood control, selected overstory pines on all 16 plots were commercially logged, leaving a residual basal area of $16 \mathrm{~m}^{2}$ ha- ${ }^{1}$. In summer 1987 , a second improvement cut further reduced merchantable-pine basal area to $12 \mathrm{~m}^{2} \mathrm{ha}^{-1}$ withavolumeof $122 \mathrm{~m}^{3} \mathrm{ha}^{-1}$.

Five years after hardwood control, pine and hardwood measurements were taken and herbaceous competition assessments were made using the same 
procedures as described in Study A. These measurements were taken within nine circular subplots ( $1.2 \mathrm{~m}^{2}$ each) per 0.04 ha interior plot.

Two herbicides were used in Studies $\mathbf{A}$ and $\mathbf{B}^{1}$, Tordon ${ }^{\circledR}$ (Picloram (4-amino-3,5,6-trichloropicolinic acid) and 2,4-D (2,4-dichlorophenoxyacetic acid) for stem injection and foliar application and Velpar ${ }^{\circledR}$ (Hexazinone [3-cyclohexyl-6- (dimethylamino )- 1 -methyl- 1,3,5-triazine-2,4 ( $1 \mathrm{H}, 3 \mathrm{H})$ dione] ) for soil application.

\section{Demonstration A (selection management)}

A 14 ha tract of timber was set aside in 1937 as a farm forestry study. To encourage the establishment of pine reproduction, the upper limits of pine stocking were not to exceed $18 \mathrm{~m}^{2}$ ha-' basal area with a merchantable volume of $140 \mathrm{~m}^{3}$ ha-'. This tract of timber was intensively managed for 30 years, through the late 1960s. Hardwoods were periodically controlled by girdling in early years of management and later by stem injection and mistblowing with herbicides. A single-tree selection harvest was made in 197 1, but no competition control treatments were imposed throughout the 1970s. Subsequently, the area became overrun with understory hardwoods in combination with Japanese honeysuckle (Lonicera japonica Thunb. ).

Understory vegetation was reduced by rotary mowing in summer 1978 to provide access for a $100 \%$ inventory of merchantable-size pines $(9.1 \mathrm{~cm}$ or greater dbh). Regulated uneven-aged management was reinstituted in 1979 by cutting back to $15 \mathrm{~m}^{2}$ ha- ${ }^{1}$ of pine basal area in trees of $9.1 \mathrm{~cm}$ or greater

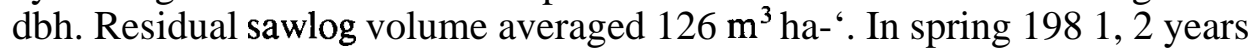
after mowing and 1 year after the selection harvest, a $1 \%$ inventory of the area was conducted using $5 \mathrm{~m}^{2}$ sample quadrats to assess subjectively the prevalence of Japanese honeysuckle.

In autumn 1985, another cyclic cut was made using single-tree selection. That cut left $13 \mathrm{~m}^{2}$ ha-' of merchantable pine basal area and a sawlog volume of $114 \mathrm{~m}^{3}$ ha- $^{1}$. In spring 1986, Velpar L herbicide was applied at a rate of $3.36 \mathrm{~kg}$ ha- ${ }^{1}$ active ingredient (a.i. ) on a $0.9 \mathrm{mx} 0.9 \mathrm{~m}$ grid, using spotguns, to control nonpine vegetation over the entire 14 ha.

Pine regeneration data were collected in winter 1982 and summer 1989 from $1004-\mathrm{m}^{2}$ quadrats that were systematically spaced across the 14 ha study area. Submerchantable pines were counted by size class for seedlings ( $15 \mathrm{~cm}$ tall to $1.4 \mathrm{~cm} \mathrm{dbh}$ ) and saplings $(1.5-9.0 \mathrm{~cm} \mathrm{dbh})$. Each $4 \mathrm{~m}^{2}$ quadrat was assessed as being overtopped by competing vegetation in accordance with freeto-grow criteria. Japanese honeysuckle ground coverage was estimated by eye to the nearest $10 \%$ during the 1989 inventory.

'Treatments involved the use of herbicides, but their discussion in this paper is not a recommendation of their use and does not imply that uses discussed here are registered. 


\section{Demonstration $B$ (selection management)}

In 1983, a 24 ha tract was placed under even-aged management for hardwoods along an ephemeral drainage. Uneven-aged management was used for pine-hardwoods on the first terrace bordering either side of the drainage, and for pines on the upland sites beyond the pine-hardwood terraces. Data for this paper were taken from 8.9 ha that comprised the pine-only management area. When an inventory of that area was first made in 1980, the area contained $14 \mathrm{~m}^{2}$ ha-' of merchantable pine basal area and $133 \mathrm{~m}^{3}$ ha-' of volume with and uneven-aged stand structure. There was also a substantial midstory hardwood component consisting of 237 trees ha-' that were of $9.1 \mathrm{~cm}$ or greater dbh, with a basal area of $5 \mathrm{~m}^{2}$ ha- ${ }^{1}$ and an average dbh of $16.5 \mathrm{~cm}$. Neither the submerchantable hardwoods nor pines were recorded but the few submerchantable pine saplings that did occur were too suppressed to be considered as future crop trees.

In summer 1983, a commercial timber harvest removed all merchantable hardwoods and reduced pine stocking to $11 \mathrm{~m}^{2}$ ha- ${ }^{1}$ of basal area and $98 \mathrm{~m}^{3}$ ha- ${ }^{1}$ of volume using the single-tree selection system. In spring 1985, Velpar $\mathrm{L}$ herbicide was applied with spotguns at a rate of $3.9 \mathrm{~kg} \mathrm{ha}^{-1}$ a.i. on a 1.2 $\mathrm{m} \times 1.2 \mathrm{~m}$ grid to control non-pine competition. Another 5-year cycle-cut was conducted in summer 1988 to maintain a post-harvest basal area of $13 \mathrm{~m}^{2}$ ha- ${ }^{1}$ in merchantable-size pines.

Pine regeneration data for this paper were derived in summer 1989 from $1004 \mathrm{~m}^{2}$ quadrats that were systematically spaced across the 8.9 ha study area. Measurement procedures were the same as described above for Demonstration A.

\section{Statistical analysis}

In both Study A and Study B, analysis of variance was used to evaluate treatment effects on pine seedling development and competing vegetation. Phase I and Phase II of Study A were analyzed separately. Differences between treatment means were isolated by using Duncan's New Multiple Range Test. Because of the wide range of values, percentages were converted by arcsine transformation before analysis. All analyses were carried out at the 0.05 level of significance.

\section{RESULTS AND DISCUSSION}

\section{Pine seed crops}

One criterion for successful natural regeneration of loblolly and shortleaf pines is an adequate seed crop. An average year's seed crop for loblolly pine 
totals between 74000 and 198000 viable seeds ha-' (Baker and Balmer, 1983). Annual pine seed crops, which were monitored between 1980 and 1981 , ranged from zero to almost 3000000 potentially viable seeds ha- ${ }^{1}$, with adequate seed crops (over 100000 seeds ha- ${ }^{1}$ ) produced during seven of the 9 years. If any of the four study areas discussed in this paper failed to regenerate, it was not for lack of potentially viable seeds.

\section{Study A}

On cutover areas, natural regeneration of loblolly and shortleaf pines is considered successful if density averages 1700 trees ha- ${ }^{1}$ at the beginning of the third year (Grano, 1967 ), and at least $40 \%$ of 0.0004 ha sample quadrats are stocked after 3 years (Campbell and Mann, 1973). Based on those two criteria, all site-prepared plots had more than adequate pine densities, and quadrat-stocking exceeded the minimum threshold of 40\%, 7-8 years after treatment (Table 1). In contrast, untreated check plots failed to achieve adequate pine density or stocking. No one site treatment used in this study pro-

\section{TABLE I}

Effects of site preparation on pine regeneration development 7-8 years after treatment in Study A

\begin{tabular}{|c|c|c|c|c|c|}
\hline \multirow[t]{3}{*}{ Treatments } & \multicolumn{5}{|c|}{ Mean value } \\
\hline & \multicolumn{2}{|l|}{ All pines } & \multicolumn{3}{|c|}{ Tallest 3900 pines ha-' } \\
\hline & $\begin{array}{l}\text { Stocking" } \\
(\%)\end{array}$ & 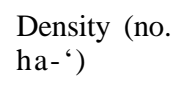 & $\begin{array}{l}\text { Gld }^{\mathrm{b}} \\
(\mathrm{mm})\end{array}$ & $\begin{array}{l}\text { Total height } \\
\text { (m) }\end{array}$ & $\begin{array}{l}\text { Free-to-grow } \\
(\%)\end{array}$ \\
\hline \multicolumn{6}{|l|}{ Phase I } \\
\hline Check' & 0 & 0 & & & - \\
\hline $\log$ & $46 a^{d}$ & $3954 a$ & $11 \mathrm{a}$ & $1.10 \mathrm{a}$ & $20 \mathrm{a}$ \\
\hline $\begin{array}{c}\text { Burn }+ \text { foliar } \\
\text { herbicide }\end{array}$ & $71 \mathrm{a}$ & $5930 \mathrm{a}$ & $10 \mathrm{a}$ & $0.93 \mathrm{a}$ & $24 \mathrm{a}$ \\
\hline Mow + disk & $67 \mathrm{a}$ & $5107 a$ & $17 \mathrm{a}$ & $1.14 \mathrm{a}$ & $15 \mathrm{a}$ \\
\hline Error mean square & 1002 & $23103 \times 10^{3}$ & 113 & 0.49 & 321 \\
\hline \multicolumn{6}{|l|}{ Phase II } \\
\hline Check' & 19 & 371 & 2 & 0.15 & 0 \\
\hline Mow+disk & $88 \mathrm{a}$ & $16061 \mathrm{a}$ & $13 a$ & $1.29 \mathrm{a}$ & 41 \\
\hline Mow + herbicide & $69 a$ & $8896 a$ & $5 \mathrm{a}$ & $0.54 \mathrm{a}$ & 0 \\
\hline Error mean square & 253 & $10375 \times 10^{4}$ & 44 & 0.36 & 327 \\
\hline
\end{tabular}

"(Number of occupied quadrats/total number of quadrats) $\times 100$.

"Groundline diameter.

'Not included in statistical analyses because there was no pine regeneration on the six check plots in Phase I, nor on two of four check plots in Phase II.

${ }^{\mathrm{d}}$ For each phase, within-column means followed by the same letter are not significantly different $(P<0.05)$. 
duced significant pine growth gains when compared with any of the others except untreated checks.

Even though establishment of pine regeneration was easily achieved, development of that regeneration was poor during the ensuing 7-8 years. Poor growth response was indicated by the small size of dominant seedlings, which had an average height of only $0.5-1.3 \mathrm{~m}$ on site-prepared plots (Table 1). Several factors account for the lack of pine growth response: rapid reinvasion of herbaceous and woody vegetation, small canopy gaps, and adjacent uneven-aged stands that remained overstocked throughout the 8 year study. Early successional plant species were already well entrenched within the gaps when the study began and were only temporarily controlled by the treatments. As a result, $0-41 \%$ of dominant seedlings were judged as free-to-grow 7-8 years after treatments were imposed (Table 1). At that time, mean height of woody rootstocks on site-prepared plots averaged about $0.3 \mathrm{~m}$ taller than the mean height of dominant pines. Density of non-pine woody rootstocks ranged from 29700 stems ha-' on treated plots in Phase II to 37100 stems ha-' on treated plots in Phase I. Acer rubrum L., Callicarpa americana L., Cornus florida L., Quercus nigra L., and Vaccinium spp. L. accounted for over $60 \%$ of all woody species recorded after 7 and 8 years. Because of multistoried layers, ground coverage by woody and herbaceous vegetation totalled over $100 \%$. In terms of ground coverage, pine seedlings represented less than $9 \%$ of the total.

Herbaceous vegetation (i.e. grasses, forbs, vines, and semi-woody plants) can reduce the growth of naturally established pine seedlings in both evenaged stands (Cain, 1988b) and uneven-aged stands (Cain, 1985) of loblollyshortleaf pines. The principal herbaceous species on these sites include Andropogon spp. L., Lonicera japonica Thunb., Panicum spp. L., Rubus spp. L., Smilax spp. L., Uniola spp. L., and Vitis spp. L. McDonald ( 1986) reported that grasses hinder the establishment and growth of conifers in plantations by preempting resources, by allelopathy, and by attraction of insects and animals. Such opposing forces might be even more critical to the germination and subsequent growth of naturally regenerated pine seedlings.

Canopy gaps of 0.04 ha $(20 \mathrm{~m} \times 20 \mathrm{~m})$ used in Study A were large enough to permit establishment of intolerant pine seedlings. Wahlenberg ( 1948), for example, reported that survival and height growth of loblolly pine seedlings in Arkansas were best under overstory openings of $13 \mathrm{~m}$ in diameter or larger. In the present study, however, pine seedling growth was impaired. Earlymorning and late-afternoon sunlight was excluded from the openings because of an overstocked pine canopy and midstory hardwood component that surrounded the openings. Also, competing vegetation in the canopy gaps was only temporarily controlled and had completely reoccupied the plots within 3 years of treatment. Therefore, use of the selection reproduction cutting method for sustained yield requires a commitment to manage an entire stand at regular intervals rather than treatment of canopy gaps. That management 
includes controlling competing vegetation and maintaining merchantable pine basal areas of 13-18 $\mathrm{m}^{2}$ ha- $^{1}$, as indicated by long-term results from research on uneven-aged stands (Baker, 1986).

\section{Study B}

Unlike the treatment areas in Study A, which were occupied by early successional herbaceous and woody vegetation at the time of installation, study area B was almost devoid of herbaceous ground cover. A dense hardwood understory ( 11500 stems ha- $^{1}$ ), hardwood midstory ( 5800 stems ha- ${ }^{1}$ ), and a pine overstory basal area of about $23 \mathrm{~m}^{2}$ ha- ${ }^{1}$ in this even-aged loblollyshortleaf stand had obstructed the sunlight from reaching the forest floor for 10- 15 years and thereby suppressed establishment of intolerant herbaceous plants. That, however, may be only a part of the exclusion process. In some instances, severe competition for soil moisture can eliminate subordinate layers of vegetation in forest stands (Korstian and Coile, 1938 ). It has also been reported that some species of forest trees, such as Quercus spp., may preclude or retard the growth of grasses and vines by allelopathic effects (Hook and Stubbs, 1967; DeBell, 197 1; Fisher, 1980).

Although pine seedling density and quadrat stocking were adequate on check plots at the end of 5 years, dominant seedlings averaged less than $0.3 \mathrm{~m}$ tall (Table 2). The methods of hardwood control that were used in this study appear to be unimportant as differences in seedling size and free-to-grow condition among treatments were not statistically significant. What is important, however, is the fact that pine seedlings on treated plots with residual pine

\section{TABLE 2}

Effects of preharvest hardwood control on pine regeneration development 5 years after treatment in Study B

\begin{tabular}{|c|c|c|c|c|c|}
\hline \multirow[t]{3}{*}{ Treatments } & \multicolumn{5}{|c|}{ Mean value } \\
\hline & \multicolumn{2}{|l|}{ All pines } & \multicolumn{3}{|c|}{ Tallest 3700 pines ha-' } \\
\hline & $\begin{array}{l}\text { Stocking" } \\
(\%)\end{array}$ & $\begin{array}{l}\text { Density (no. } \\
\text { ha-") }\end{array}$ & $\begin{array}{l}\text { Gld }^{\mathbf{b}} \\
(\mathrm{mm})\end{array}$ & $\begin{array}{l}\text { Total height } \\
\text { (m) }\end{array}$ & $\begin{array}{l}\text { Free-to-grow } \\
(\%)\end{array}$ \\
\hline Check & $50 a^{c}$ & $16922 \mathrm{a}$ & $3 a$ & $0.21 \mathrm{a}$ & $12 \mathrm{a}$ \\
\hline Inject & $86 b$ & $34990 \mathrm{a}$ & $16 \mathrm{~b}$ & $1.37 \mathrm{~b}$ & $81 \mathrm{~b}$ \\
\hline Soil herbicide & $75 \mathrm{ab}$ & $30873 a$ & $11 \mathrm{ab}$ & $1.05 \mathrm{~b}$ & $62 b$ \\
\hline Mow + spray & $81 \mathrm{ab}$ & $66091 b$ & $18 \mathrm{~b}$ & $1.63 \mathrm{~b}$ & $75 b$ \\
\hline Error mean square & 160 & $22373 \times 10^{4}$ & 34 & 0.22 & 489 \\
\hline
\end{tabular}

a (Number of occupied quadrats/total number of quadrats) X 100.

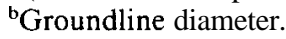

'Within-column means followed by the same letter are not significantly different $(P<0.05)$. 
overwood averaged $0.3 \mathrm{~m}$ taller after 5 years (Table 2) than pine seedlings after 7 or 8 years on plots without pine overwood (Table 1). Also, 62-8 1\% of dominant pines were free-to-grow on treated plots in Study B, but O-4 1\% were free-to-grow in Study A. That is because dominant pines on treated plots in Study B averaged about $0.6 \mathrm{~m}$ taller than the mean height of woody competition. Density of hardwood rootstocks on plots in Study B averaged about 34600 stems ha- ${ }^{1}$ after 5 years and was similar to rootstock density on plots in Study A. Acer rubrum L., Callicarpa americana L., Cornus florida L., and Vaccinium spp. L. accounted for $76 \%$ of all woody competition in Study B; therefore, species richness of woody plants was similar in both studies. Combined ground coverage by herbaceous and woody vegetation on treated plots in Study B averaged $87 \%$ after 5 years, and the contribution of pine regeneration to ground coverage on hardwood control plots averaged $16 \%$.

Data from these two studies suggest the following observation: on upland pine sites, there appears to be an antagonistic symbiosis (Oosting, 1956) between pines and hardwoods that occurs naturally, but that can be artificially enhanced by alternation of species. Although indigenous hardwood species on upland sites effectively preclude establishment of pines in the absence of disturbance, they also preclude herbaceous vegetation. It is that second function of hardwoods that appears to be the most important for the successful establishment and early growth of future generations of pines. This observation is substantiated by data from two demonstration areas in the Experimental Forest that were regenerated within the same time frame as Studies A and B using selection management and operational vegetation control techniques.

\section{Demonstration A}

According to Reynolds ( 1959), a well-stocked, uneven-aged loblolly-shortleaf pine stand should contain at least 247 stems ha-' in the seedling to 10 $\mathrm{cm}$ dbh class. Using his criterion, the percentage of submerchantable-size stems within the mid-range of four size classes would be: seedlings $-32 \%, 2.5$ $\mathrm{cm}-27 \%, 5.1 \mathrm{~cm}-23 \%$, and $7.6 \mathrm{~cm}-18 \%$.

An inventory of submerchantable pines was conducted in December 1982, 4 years after mowing and 3 years after a cycle cut. Only $20 \%$ of sampled quadrats were stocked with submerchantable pines and density averaged 1360 stems ha-'. Although overall density was adequate, distribution within the four submerchantable size classes was not. Only $2 \%$ of those 1360 stems had reached sapling size $(1.5-9.0 \mathrm{~cm}$ dbh) whereas $68 \%$ is required when diameter distributions are regulated. Lack of pine regeneration in the sapling size classes is attributed to the absence of vegetation management between 1968 and 1978.

Japanese honeysuckle first appeared in this area in the late 1950s (R.R. Reynolds, personal communication, 1979) and there is no historical 
documentation to suggest that any cultural treatment was employed to control its spread. Although this perennial vine provides excellent cover and browse for wildlife, it is detrimental to natural regeneration of trees (Oosting, 1956). An inventory of its prevalence in spring 1981 revealed that $85 \%$ of sample quadrats on the 14 ha contained a medium to dense ground cover of Japanese honeysuckle.

A second inventory of submerchantable pines was conducted in summer 1989. In that survey, 53\% of sampled quadrats were stocked with pine regeneration and density averaged 9980 stems ha- ${ }^{\circ}$. Both the seedling and the 1.5$3.9 \mathrm{~cm}$ dbh classes were adequately stocked in accordance with the desirable distribution for uneven-aged stands (Fig. 1). Four events, which occurred after the 1982 inventory, account for the increase in pine density and per cent stocking. One event was a bumper pine seed crop in winter 1983-1 984. That event was followed by site disturbance from a cyclic cut in autumn 1985 . Probably the two most important events were the broadcast application of a soil-active herbicide in spring 1986 and a second bumper pine seed crop that winter.

Based on the 1989 inventory, the submerchantable pine component appeared to be well on the way to recovery but there were still problems associated with herbaceous and woody competition. For example, Japanese honeysuckle was still present on $94 \%$ of the quadrats sampled in 1989, and average ground coverage by that vine was judged to be $45 \%$. Also, $57 \%$ of sampled

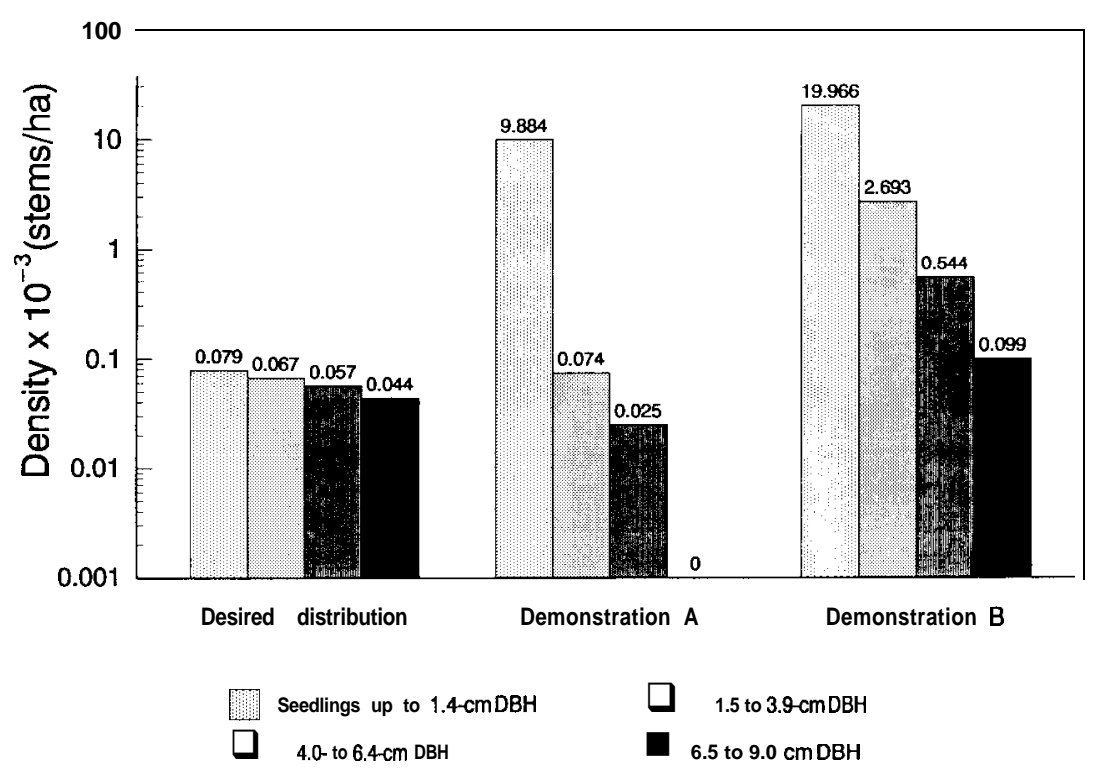

Fig. 1. Diameter distributions for submerchantable pines in uneven-aged loblolly-shortleaf pine stands. 
quadrats were judged to be overtopped by woody non-pine competition, principally Callicarpa americana L., which is not controlled by Velpar (McLemore, 1983).

\section{Demonstration $B$}

When selection pine management was initiated in 1983, this demonstration area was very similar to that in Study B; that is, the forest floor was almost devoid of herbaceous vegetation because of a mature pine overstory and a dense hardwood midstory and understory. However, unlike the stand in Study B, which was even-aged, the merchantable pine component in this stand had an uneven-aged structure.

Stocking of pine regeneration in 1989 was $89 \%$ with an overall density of

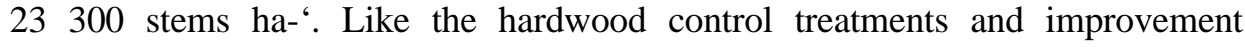
cut in Study B, the soil-applied herbicide and selection harvest on this demonstration area were applied in spring and summer 1983, just ahead of a bumper pine seed crop that winter. Six years after the cyclic harvest and hardwood control, $49 \%$ of sampled quadrats were judged as overtopped by woody non-pine competition, but unlike Demonstration A, there was no Japanese honeysuckle. Even though the 1983-1 984 pine seed crop contributed to most of the stems that were recorded in 1989, individual pine seedlings and saplings had already begun to express dominance. That is illustrated in Fig. 1 by their apportionment within the four submerchantable size classes.

During a 6 year period on Demonstration B, pine regeneration had become well established in all four submerchantable size classes, whereas pine regeneration on Demonstration A had not, even after 10 years (Fig. 1). What factors might account for those disparities between the two areas?

One might infer that hardwood control on Demonstration B during spring 1983 in combination with a bumper pine seed crop the next winter either contributed to or resulted in the pine regeneration differences between Demonstration areas A and B. However, a bumper pine seed crop in winter 19861987 also coincided with a broadcast herbicide treatment on Demonstration A the previous spring. Therefore, with two bumper pine seed crops on Demonstration A ( 1983-1984 and 1986-1987), as well as vegetation management, it could be argued that a more favorable differentiation of submerchantable pine size classes should have been expected on that area after 10 years compared with what occurred on Demonstration B after only 6 years.

As the 6 year regeneration interval for Demonstration B fell within the 10 year regeneration interval for Demonstration A, differences in the size of pine regeneration between the two areas are not likely to be attributed to rainfall patterns. Similarly, overtopping of sampled quadrats by merchantable-size pines and woody non-pine competition on Demonstration A (79\%) was not much more than on Demonstration B (72\%) when the regeneration surveys 


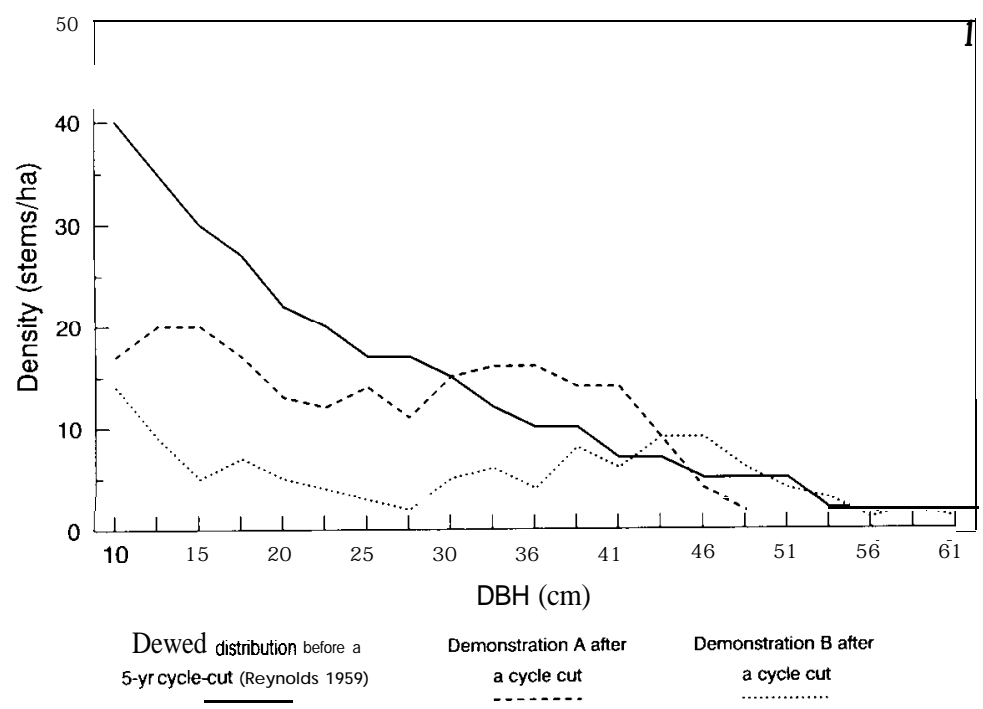

Fig. 2. Diameter distributions for merchantable pines in uneven-aged loblolly-shortleaf pine stands.

were conducted in summer 1989. Although density of merchantable-size pines, less than $44 \mathrm{~cm} \mathrm{dbh}$, was higher on Demonstration A compared with that on Demonstration $\mathrm{B}$, diameter distributions on both areas were unbalanced and were considerably less than the desirable densities for a balanced uneven-aged loblolly-shortleaf pine stand (Fig. 2).

These data suggest that lack of adequate pine regeneration in the two larger submerchantable size classes of Demonstration A can be attributed to the presence of a vigorous herbaceous ground cover, particularly Japanese honeysuckle, that reduced individual tree growth.

\section{SUMMARY AND CONCLUSIONS}

In stands dominated by loblolly and shortleaf pines, midstory and understory hardwood species appear to act as intermediaries for successful natural pine regeneration. That is accomplished by their shading of the ground surface, soil moisture depletion, or, in some cases, allelopathic effects which serve to preclude the invasion and growth of herbaceous vegetation in fully stocked stands. When natural pine regeneration is desired, merchantable pines should be harvested according to any of the recommended reproduction cutting methods. At that time, hardwoods should be removed by harvest or vegetation control techniques, and the site should become occupied at the same point in time by pine seedlings, herbaceous species, and hardwood sprouts or seedlings. Given an equal opportunity to compete for limited resources, naturally 
established pine seedlings exhibit rapid growth in height and can dominate a site in 5-7 years.

If a multitude of dense vines and grasses are already present on the site, then intensive seedbed preparation or vegetation management will most probably be required to control those plants adequately and insure adequate pine regeneration. Examples of herbaceous competition problems include the prevalence of briars and grasses in canopy gaps, or exotic vines that thrive under full- to intermediate-light intensities within fully stocked even-aged and uneven-aged pine stands. In the absence of disturbance, the existing herbaceous vegetation aggressively competes with the pine seedlings and may result in failure of the regeneration effort. Even when pine seedling density and stocking are adequate for successful regeneration, a rank ground cover of herbaceous species can reduce pine growth and may dictate the application of release treatments.

This paper is not meant to imply that an indigenous hardwood component must be maintained as an integral part of natural loblolly and shortleaf pine management on upland sites. In fact, a substantial hardwood component in pine stands will most certainly decrease pine volume production, and, in the absence of disturbance, will displace the pines to form a hardwood climax. From the standpoint of natural pine regeneration, however, and given the same degree of vegetation management, a pine forest that contains midstory and understory hardwoods is more likely to be successfully regenerated with pines in a shorter period of time after hardwood control than a similar forest that is occupied by established herbaceous vegetation.

\section{REFERENCES}

Baker, J.B., 1986. The Crossett farm forestry forties after 41 years of selection management. South. J. Appl. For., 10: 233-237.

Baker, J.B. and Balmer, W.E., 1983. Loblolly pine. In: Silvicultural Systems for the Major Forest Types of the United States. US Dep. Agric., Agric. Handb., 445: 148- 152.

Bonner, F.T.. 1974. Seed testing. In: Seeds of Woody Plants in the United States. US Dep. Agric., Agric. Handb., 450: 136-1 52.

Burkhart, H.E., Glover, G.R. and Sprinz, P.T., 1987. Loblolly pine growth and yield response to vegetation management. In: J.D. Walstad and P.J. Kuch (Editors), Forest Vegetation Management for Conifer Production. John Wiley, New York, pp. 243-271.

Cain, M.D., 1985. Japanese honeysuckle and associated ground cover inhibit establishment and growth of pine seedlings in all-aged stands. In: E. Shoulders (Editor), Proceedings of the Third Biennial Southern Silvicultural Research Conference. US Dep. Agric. For. Serv. Gen. Tech. Rep. SO-54, South. For. Exp. Sta., New Orleans, LA, pp. 300-304.

Cain, M.D., 1987. Site-preparation techniques for establishing natural pine regeneration on small forest properties. South. J. Appl. For., 1 1: 41-45.

Cain, M.D., 1988a. Hardwood control before harvest improves natural pine regeneration. US Dep. Agric. For. Serv. Res. Pap. SO-249, South. For. Exp. Sta., New Orleans, LA, 6 pp. 
Cain, M.D., 1988b. Competition impacts on growth of naturally regenerated loblolly pine seedlings. U.S. Dep. Agric. For. Serv. Res. Note SO-345, South. For. Exp. Sta., New Orleans, LA, 5 PP.

Cain, M.D. and Yaussy, D.A., 1984. Can hardwoods be eradicated from pine sites? South. J. Appl. For., 8: 7-1 3.

Campbell, T.E. and Mann, W.F., Jr., 1973. Regenerating loblolly pine by direct seeding, natural seeding, and planting. US Dep. Agric. For. Serv. Res. Pap. SO-84, South. For. Exp. Sta., New Orleans. LA, 9 pp.

DeBell, D.S., 197 I. Phytotoxic effects of cherrybark oak. For. Sci., 17:180-185.

Fisher, R.F., 1980. Allelopathy: a potential cause of regeneration failure. J. For., 78: 346-348.

Grano. C.X., 1967. Growing loblolly and shortleaf pine in the midsouth. US Dep. Agric. Farmer's Bull., 2 102, 27 pp.

Hook, D.D. and Stubbs, J., 1967. An observation of understory growth retardation under three species of oaks. US Dep. Agric. For. Serv. Res. Pap. SE-70, Southeast. For. Exp. Sta., Asheville. NC, 7 pp.

Korstian. C.F. and Coile, T.S., 1938. Plant competition in forest stands. Duke Univ. School For. Bull., 3, 125 pp.

McDonald, P.M., 1986. Grasses in young conifer plantations - hindrance and help. Northwest Sci., $60(4)$ : 271-278.

McLemore, B.F., 1983. Four formulations of hexazinone for controlling hardwoods in pine stands. Proc. South. Weed Sci. Soc., 36: 2 12-217.

Oosting. H.J., 1956. The Study of Plant Communities. W.H. Freeman, San Francisco, 440 pp.

Reynolds, R.R., 1959. Eighteen years of selection timber management on the Crossett Experimental Forest. US Dep. Agric. Tech. Bull., 1206, 68 pp.

USDA, 1979. Soil survey of Ashley County. US Dep. Agric. Soil Conserv. Serv., For. Serv., and Ark. Agric. Exp. Sta., Washington, DC, 92 pp. and maps.

USDA, Forest Service, 1988. The South's fourth forest: alternatives for the future. US Dep. Agric. For. Serv. For. Resour. Rep., 24, 512 pp.

Wahlenberg. W.G., 1948. Effect of forest shade and openings on loblolly pine seedlings. J. For., 46: 832-834. 